The Geneva Papers on Risk and Insurance, 21 (No. 79, April 1996) 258-270

\title{
Pensions as Insurance
}

\author{
by Richard Disney*
}

\section{Introduction}

The "pensions as insurance" literature is large and growing. Following a seminal paper by Diamond (1977), consideration was given to the conditions under which private markets might be unable to deliver actuarially-fair annuities, and as to under what circumstances state intervention might be justified. However the concern as to the optimal form and extent of state intervention in the annuity market can be traced back at least to Samuelson (e.g. 1975). The literature on welfare-enhancing state provision has continued to expand, at least until the mid-1980s. The arguments are surveyed in Sections 2 and 3 below. One problem, discussed in Section 3, is that state provision of social security in practice rarely conforms to the form suggested by theoretical models of welfare-improving state intervention.

From the mid-1980 onwards, there has been a shift of focus towards consideration of types of pension provision within the private sector, rather than consideration simply of the optimal mix of state and private pensions. This shift in focus reflects changes in private pension provision, particularly in North America and the UK; notably the growth in take-up of tax-privileged retirement savings accounts such as IRAs and 401k plans in the US, and Personal Pensions in the UK. Indeed Chile has seen a total switch away from "traditional" PAYG social insurance towards this form of pension provision. Two specific issues which have emerged are (i) that other assets may be perceived primarily as providing income in retirement, and (ii) that different types of pension provision may provide at least partial insurance against other types of risk than longevity risk. These issues are considered in Section 4, and the final section "Evaluation" brings some of these points together.

* Professor of Economics, Queen Mary \& Westfield College, University of London, and Research Fellow, Institute for Fiscal Studies. This paper was presented at a Workshop on the Boundary between Private and Social Insurance, University of Nottingham, October 18, 1994. Thanks go to participants, and an anonymous referee, for comments on an earlier draft. 


\section{Pensions as longevity insurance: the possibility of market failure}

What insurance does a pension instrument provide? The standard argument in the context of the life cycle model of saving is that a pension scheme gives insurance against longevity risk : provision of annuities at an actuarially fair premium is welfare-improving if individuals are risk averse to uncertainty as to timing of death. Indeed with a high degree of risk insurance aversion, even unfair annuities may be attractive. Yet it is well known that "free standing" annuity markets are thin even in sophisticated capital markets such as the UK and the US and that annuity rates are rather unattractive; at least, relative to average risks.

One possible reason for this thinness is adverse selection, where insurers cannot monitor individual-specific longevity and retirement risks effectively. With adverse selection (private information on survival risks), several equilibria are possible. Given competition among insurers over both prices and quantities in the presence of private information (Rothschild and Stiglitz, 1976), the appropriate concept of market equilibrium depends on assumptions as to any provider's perceptions concerning the behaviour of competing annuity providers (Wilson, 1977). Thus, notwithstanding the evidence both for the US and the UK that annuitants are not a "representative" sample of the population, and that premia are far from actuarially fair (Friedman and Warshawsky, 1988, 1990; Brugiavini, 1990), it has been argued that such measures do not take account of restrictions on the quantities of annuities provided where there is adverse selection (Brugiavini, 1990, 1993). ${ }^{1}$

Eichenbaum and Peled (1987) explore the consequences for asset portfolios of adverse selection. Typically, individuals with a lower survival probability will face actuarially unfair annuities and so will hold a greater proportion of their wealth in assets other than annuities (i.e. bequeathable wealth). In turn the distortion of relative returns between annuities and bequeathable wealth imposes externalities on other purchasers: some form of compulsion in annuity purchase will be Pareto-improving, even if there is redistribution in a pooled equilibrium. This however states a possible case for state intervention (such as regulation), and not for state provision per se.

An important issue is whether by precommitment (that is, by the optimal timing of annuity purchases) adverse selection problems can be ameliorated (Eckstein, Eichenbaum and Peled, 1985 ; Brugiavini, 1993). As a potential difficulty to this solution, it is often asserted that young people are myopic and unwilling to make optimal pension arrangements at an early enough stage of their working life. Furthermore, there is a case to be made for deferring purchases until relevant information is revealed if the demand for annuities is not known early in the working life and if potential adverse selection problems are not substantial.

In the context of myopia, the substantial rate of take-up of Personal Pensions in the late 1980s and early 1990s among younger workers in the UK (40\% + among eligible workers: see Disney and Whitehouse, 1992; Dilnot et al, 1994, Figures 2.3 and 2.7) might be interpreted as suggesting that myopia among young people was not a major problem. Of course, the heavy advertising of Personal Pensions and the tax incentives offered to optants were major factors in this high take-up, and many young purchasers have not invested anything more

1 Another possible market failure is wherc purchasing the annuity induces the insured person to change their behaviour in order to prolong their life. This possibility seems more far-fetched, but is discussed in Kuhn and Davies (1988). 
than the statutory ininimum contracted-out rebate in their Personal Pension. Nevertheless opting out of the state earning-related pension in order to buy a Personal Pension requires a positive decision and the extent of take-up far exceeded that anticipated by the Department of Social Security. Furthermore optants may build up their contribution rates as their annual real incomes increase over the life cycle.

There are other reasons for the thinness of the "free standing" annuity market. The first is the existence of social insurance and of company-provided pension plans which "crowd out" individually purchased annuities. As a consequence, some individuals may perceive themselves to be overannuitised (Bernheim, 1991) because they wish to retire holding a portfolio of assets in addition to annuities. Furthermore, although not providing longevity insurance as such, assets such as unit trusts (mutual funds in the US) and, in their tax relieved form, Personal Equity Plans (PEPs) may be regarded as approximate substitutes by many holders. Even bequeathable assets such as home ownership contain insurance characteristics which overlap with those available from annuities and which may indeed be superior from the point of view of prospective retirement income. For example, annuity values are highly dependent on stock market performance and the timing of retirement behaviour, whereas it may be possible to time equity release from housing to take advantage of favourable circumstances (Leather, 1990; Disney, Gallagher and Henley, 1994).

Finally, and most crucially, different assets obtain different tax privileges, and this will tend to shift demand away from markets with relatively unfavourable tax treatment (such as "free standing" annuities and, since 1984, life insurance in the UK) towards more attractive options (in the UK, housing, especially in the early 1980s; company pension schemes and, since the late 1980s, Personal Pensions, PEPs and TESSAs. For the US, see the recent discussion in Engen, Gale and Scholz, 1994). Thus the thinness of the annuity market probably says little about the demand for longevity insurance, nor indeed does it rule out the possibility of its oversupply through institutional provision. This oversupply can take the form of excess holdings of pension instruments in retirement relative to other assets, or of excessive transfers of consumption across the life cycle; evidence that individuals may in effect have replacement ratios exceeding well over $100 \%$ in retirement in the US is contained in Boskin and Shoven, 1987. This may well imply an "excessive" transfer of lifetime consumption to old age given the standard Euler condition for inter-temporal optimisation of life cycle consumption.

\section{Should the state intervene to provide pension insurance?}

The previous argument implied that poverty in old age largely stems from a paucity of lifetime resources, rather than a failure of available instruments in the capital market through which lifetime resources could be transferred from periods of economic activity to retirement. Thus the state may have a role in providing pensions through the social security programme as a form of poverty alleviation. This might imply state intervention on a very selective basis, except that the form of state provision will have an impact on consumption behaviour and on asset holding. For example an asset-tested income "floor" in retirement, such as Income Support in the UK, will affect life cycle consumption behaviour (Hubbard, Skinner and Zeldes, 1995). Indeed there is clear evidence that programmes which provide largely income and asset tested state pensions, such as Australia, induce substantial distortions to household savings behaviour (Creedy and Disney, 1989). Thus a poverty alleviation motive and universality of provision of at least a minimum pension are not incompatible. 
The question posed here is different: should the state provide pensions on insurance grounds, and if so, what kind of state pension provision is welfare-improving? Traditionally, market failure in the capital market (the issue of annuities discussed previously) and myopia provide two rationales for more extensive state provision of pensions (Diamond, 1977). For example, Eckstein, Eichenbaum and Peled (1985) suggest that the government might provide a "basic" compulsory annuity component, financed by the contribution of a prespecified amount when young and providing the average actuarially-fair return in old age. Supplementary provision would allow individual-specific annuities (a separating equilibrium of some form). But although this sounds superficially like the original Beveridge plan of a flat rate (lump sum) minimum "social insurance" scheme supplemented by private provision, there is little evidence that the state has been responsive to individual demand for pensions, particularly as to the form that state pension provision should take. ${ }^{2}$

Barr (1992) has argued that adverse selection is sufficient to justify welfare improving state intervention in pension provision. As Sinn (1995) points out, however, state provision in such a context may only be shown to be welfare-enhancing if we are prepared to impose some strong interpersonal comparisons e.g. utilitarianism. Even this welfare improvement may not be clear cut: adverse selection may take the form of rationing (exclusion) of pension provision for certain high risks, or it may take the form of unfair premia for some risks, depending on the nature of the private equilibrium. But the redistributive impact of a state scheme of "social insurance" which pools risks is far from clear-cut. As Schioppa (1990) points out in the Italian context and Creedy, Disney and Whitehouse (1993) and Disney and Whitehouse (1993) in the UK context, much of the intragenerational and intergenerational redistribution engendered in practice by state "social insurance" is undesirable by any reasonable welfare criterion.

Sinn (1995) argues that it is the redistributive component of social insurance itself which is the efficiency enhancing device. This is because, in the absence of redistributive mechanisms, risk averse individuals will choose less risky strategies in the context of a mean-variance trade-off of economic opportunities. By insuring against risky outcomes (such as periods of unemployment), social insurance allows individuals to adopt strategies with a higher expected pay-off but with greater spread of potential outcomes (this is a parallel argument to much of the optimal tax literature). This provides a neat link between the redistributive and efficiency arguments for state provision, although it too suffers from the presumption that redistributive outcomes are of a particular form; a presumption which may not be justified in practice.

A final "traditional" insurance argument for state intervention other than poverty alleviation put forward by Diamond, and emphasised previously in the Beveridge Report, is technology-related: due to economies of scale, or the absence of a profit markup, the state can provide social insurance programmes at lower cost than the private sector. Although this argument is often adduced, it is hard to find plausible evidence one way or the other as we are not comparing like with like in a comparison in the UK of, say, the basic state retirement pension and a Personal Pension. The more interesting issue is whether the private pension market provides an excessively differentiated product: for example there are almost 100 Personal Pension providers in the UK, and the market may be characterised by imperfect

${ }^{2}$ In the context of UK state pension reform, see Wilson (1974), Hemming and Kay (1982), Creedy and Disney (1985) and Dilnot et al (1994) for support for this argument. 
competition. In such circumstances, excessive selling costs and misleading sales pitch may be serious issues. There is evidence that Personal Pensions have been oversold for this reason, but this is again a case for tighter regulation, rather than for state provision per se.

In summary, an "insurance" case for state provision of pensions may be made in several ways: as a traditional market failure argument (although this seems one of the least convincing rationales); as a pooled insurance "floor" to a private separating market equilibrium; as an efficient redistributive device, or because transaction costs are lower. None of these would seem to be a particularly convincing explanation of state provision in practice. Instead it seems likely that, in many countries, the revenue raising function of "pay-asyou-go" social insurance has served as a major function of state pension provision. "Social insurance", which generally has very few characteristics which are recognisably connected with insurance practice in most countries, promises future benefits to current working generations based on the prospect of richer and more numerous generations in the future. However, the Aaron-Samuelson premise has been misused in the form of unsustainable "Ponzi game" or chain letter approaches, the results of which are now being illustrated in a range of countries. ${ }^{3}$

Perhaps pessimistically, it is hard to discern any clear economic principles at work in the major series of pensions reform in the UK in the later 1960s and early 1970s, in the 1975 Act, in the debate leading to the 1986 Act and in the 1995 legislation. That these inconsistent reforms themselves generated "social insurance uncertainty", as described by Bodie (1990), is not however open to doubt. The debate on pension reform in the UK from the late 1960s to the mid-1980s between the major political parties, each with their group of academic advisors, was largely ideological with no evidence that these theoretical "motivations" for government intervention played any great role. The policies proposed by successive administrations lacked any clear popular mandate: for example as to whether pensions should be flat rate (lump sum in US parlance) or earnings related (Wilson, 1974). The complex operation of the State Earnings Related Pension Scheme (SERPS), which was introduced in 1978 and substantially curtailed in 1986, was not well understood by the public (HMSO, 1985), inadequately costed (Hemming and Kay, 1982) and its distributive implications poorly understood (Creedy, 1982; Creedy and Disney, 1985; Disney and Whitehouse, 1991; Creedy, Disney and Whitehouse, 1993). Only perhaps in the discussion in the decade since the 1985 Green Paper (HMSO, 1985) as to the optimal balance of public and private provision of pensions can any clear debate concerning principles be discerned, and it is to the optimal form of private provision, to which I now turn.

\section{Types of private pensions and their insurance properties}

There are other interesting issues concerning the appropriate form of pension provision. For example, do pensions provided institutionally, whether by employers or by the state, embody any insurance characteristics which are inherently superior to individually purchased annuities? And what form should institutional provision take - should benefits be related to years of service and to a measure of earnings (and if so, what measure), or to the investment performance of the fund?

\footnotetext{
3 This argument is taken up at greater length in Disney (1996)
} 
Traditionally company pension schemes in the UK and the US have been defined benefit (DB) schemes, in which pension benefits are related to years of service and lifetime earning (typically some measure of final earnings), but in recent years, schemes have again become popular in which pensions are related to the level of contributions and fund performance: so-called defined contribution (DC) schemes. In some cases these DC plans are individually provided, topping-up state provision (as with IRAs in the US), or substituting partially (the UK, with Personal Pensions) or almost entirely for state provision (as in the Chilean model). Other group DC plans, such as $401 \mathrm{k}$ schemes in the US, permit employers to match employee contributions, although this possibility is not ruled out with Personal Pensions in the UK, where company-provided group DC plans are also growing in importance.

\subsection{Group versus individual pension provision}

Should pensions be provided on a pooled basis or on an individual basis (leaving aside the issue of state versus private provision)? The attraction of group provision is that it permits some degree of risk pooling, allowing a greater proportion of the population to purchase annuities if there is any residual degree of adverse selection and consequent quantity constraints in the annuity market. Furthermore, there may be economies of scale in pension provision when annuities are purchased by a company or group purchaser rather than by an individual. If groups such as company workforces are relatively homogeneous, then writing the group annuity contract may be less costly than a series of individual contracts. Finally, where monitoring abilities differ amongst the group, it would be hoped that those best equipped to follow contract performance would "keep an eye on" the operation of the fund.

There are, inevitably, counter-arguments. First a pooled contract may suppress individual heterogeneity as to the ideal insurance contract. The second counter-argument raises the possibility of both agency and management slack. In making a pension contract, an individual is dealing with an agent but in an individual-specific contract, that person can be expected to be both able to transmit his or her preferences and to monitor the efforts of the agent more carefully. In contrast, it is argued, a group contract is less easy to monitor and heightens the standard "agency problem" in economic analysis of guaranteeing that the agent carries out the wishes of the purchaser, and not the agent's own objectives. "Agency slack" is one reason adduced for the substantial underperformance of US pension funds (Lakonishok, Shleifer and Vishny, 1992). To this may be added "management slack" when the pension fund is internally managed by the group provider. Finally, group provision may induce a "public good" aspect to monitoring: although it is in every scheme member's interest to ensure that the fund is properly managed, it is costly to do so, and everyone thereby assumes that someone else is doing the monitoring. The "supply" of monitoring, without tight state regulation, is thereby too low. Thus such events as the Maxwell pension fraud in the UK appear to come as a complete surprise to all participants (except, perhaps, Maxwell and his advisors).

\section{Insurance characteristics of types of pensions}

To analyse the insurance properties of the variety of possible pension instruments, it is perhaps useful to focus on the disparate insurance properties of the three broad types of pension schemes available as a supplement to the basic retirement pension in the UK:

i) the state earnings-related pension scheme (SERPS), with pension benefits calculated on average revalued lifetime earnings, financed on a PAYG basis by a payroll tax (the National Insurance contribution); 
or, by contracting-out of parts of the National Insurance contribution and relinquishing a claim on SERPS, the individual can join :

ii) an "occupational pension" scheme provided by the employer - typically until recently of the "defined benefit" (DB) form, with pension benefits related to years of service in the scheme and some measure of final earnings; or

iii) a "defined contribution" (DC) or "money purchase" scheme such as a Personal Pension, in which the value of the annuity depends on the value of contributions, the return on the accumulated fund, any individual-specific annuity factors and the timing of retirement. Some degree of risk-pooling across individuals is likely in group (such as employed-provided) DC plans which are becoming more popular, particularly in the United States. ${ }^{4}$

Table 1 examines the insurance properties of these various types of supplementary pension scheme, under various headings. My judgement as to the degree of insurance provided (ranged from "Y" = yes, through "S" = some to "N" for almost none) amongst the schemes considered is naturally somewhat arbitrary, but its rationale is spelt out in the subsequent discussion.

Table 1: Insurance characteristics of supplementary pension schemes in the UK

\begin{tabular}{|l|c|c|c|}
\hline \multicolumn{1}{|c|}{ Type of uncertainty } & SERPS & DC plan & DB plan \\
\hline Capital market & $\mathrm{Y}$ & $\mathrm{S}$ & $\mathrm{S} / \mathrm{Y}$ \\
Earnings & $\mathrm{S}$ & $\mathrm{S}$ & $\mathrm{N}$ \\
Labour market interruption & $\mathrm{S}$ & $\mathrm{S} / \mathrm{N}$ & $\mathrm{S} / \mathrm{N}$ \\
Job tenure & $\mathrm{Y}$ & $\mathrm{Y}$ & $\mathrm{S}$ \\
Social insurance & $\mathrm{N}$ & $\mathrm{S} / \mathrm{Y}$ & $\mathrm{Y}$ \\
Inflation & $\mathrm{Y}$ & $\mathrm{Y}$ & $\mathrm{S}$ \\
\hline
\end{tabular}

\subsection{Capital market uncertainty}

SERPS is a PAYG scheme, with pension benefits unrelated to the performance of the capital market. Thus it is ranked as embodying the most insurance against capital market uncertainty. Both DB (private sector) and DC plans are funded schemes, which means that the return on the accumulated fund has a direct bearing on the pension in a DC plan, and an indirect bearing on the pension in a DB plan, via the contribution rate required to maintain actuarial soundness. However, although the DC plan thereby obtains the least insurance against capital market risk, it should be borne in mind that various hedging

${ }^{4}$ Where it is projected that by the year 2000 , almost $50 \%$ of covered workers will belong to company-provided DC plans rather than DB plans (Turner, 1993). 
strategies are open to fund managers: the issue of whether a DC plan can immunise against inflation risk, or more generally smooth out fluctuations in fund values, is discussed at some length in Bodie, Marcus and Merton (1988), and Disney (1995). Furthermore, it follows that DC plan participants may be able to trade off increased insurance against higher return within their portfolios; a possibility not directly open to participants in DB schemes.

\subsection{Earnings uncertainty}

SERPS pensions benefits are (since 1986) calculated from average revalued lifetime earnings between the National Insurance "ceiling and floors": The Upper and Lower Earnings Limits. Although the differential indexation of these upper and lower bounds generate some perverse redistributive consequences in the averaging procedure (Disney and Whitehouse, 1991), SERPS broadly averages over variations in earnings. Similarly the annuity obtained from a DC plan will depend on the total value of contributions, although their timing will also determine the size of the fund for given rate of return. A flexibility available in a DC-type plan, not typically available in a social insurance plan, is to vary contributions such as to construct a "target benefit" plan. In contrast, a typical final earningsbased DB plan offers less insurance against earnings uncertainty, by typically determining pension benefits on the basis of a sub-set of lifetime earnings. There is, of course, nothing intrinsic to the DB formula which precludes providing insurance against earnings uncertainty, and forms of DB plans which obtain such insurance can be devised (Samwick, 1993); nevertheless it is observed that for incentive-compatible reasons, "traditional" DB plans very rarely do so.

\subsection{Labour market interruptions}

Certain kinds of interruptions, such as time out of the labour market for childcare or care of other dependants, as well as spells of unemployment and sickness, are offset by the credits to the basic (flat rate) retirement pension. The government has promised to extend this "home responsibility protection" to SERPS which, since the abolition of the " 20 best years" rule for determining pension benefits in 1986, does not offer explicit insurance against interruptions. In the case of a DC plan, the fund of contributions continues to accumulate interest during any periods of interruption, whereas in a DB plan, benefits are related solely to years of active tenure in the scheme. Neither private DC or DB plans typically offer other forms of insurance against work interruption. However DB plans do offer specific provisions, such as ill health retirement, which mitigate certain kinds of risk. In general supplementary pension schemes in the UK offer very little in the way of insurance against prolonged spells out of full-time employment, and there may be a significant residual role here for state intervention in the form of income transfers.

\subsection{Job tenure uncertainty}

SERPS and DC plans are fully portable between jobs. However not all DB plans allow full transfer of accumulated pension rights between schemes. Consequently, because "preserved rights" (in UK parlance) are not fully protected against inflation (see below) and do not incorporate any indexation to subsequent lifetime real earnings growth, job changers are often penalised in DB schemes. Full transferability and/or full averaging procedures in the calculation of pension entitlements would rectify this penalty, but would presumably go against the incentive-compatible aspect of DB plan provision, as well as involving greater standardisation of DB plans. 
Disney and Whitehouse (1994) show how to calculate for each individual covered by a DB plan a distribution of prospective entitlements conditional on each possible pension scheme tenure. Under the assumption of a self-financing pension plan, the distribution of individual pension entitlements under a DB or DC regime will depend on the distribution of expected tenures and the specific pension formula. Given the skewed nature of the distribution of job tenures, a majority of individuals would be better off (in strict financial terms) in a DC plan than in a "typical" DB plan where preserved (early leaver) benefits are incompletely indexed to inflation (Disney, 1995, Table 2). Whether individuals are better or worse off in an expected utility sense, however, depends on the relative "weights" attached to the different prospective sources of uncertainty in DC and DB plans (Brugiavini and Disney, 1995).

\subsection{Social insurance uncertainty}

This possibility is discussed in some detail by Bodie (1990). As suggested in Section 3, social security provision (for example eligibility conditions, benefit rates, indexation procedures and accrual factors) have been changed with great regularity in the UK, according to the political complexion of the government, and in the US and many other countries in the face of successive financing crises. Thus there is typically considerable uncertainty attached to social insurance provision. This induces potential social welfare losses by generating uncertainty as to the optimal individual saving strategy in a life cycle context. To the extent that private pension plans, whether of the DB or DC type, are independent of social security, purchase of private pension cover has an insurance property.

However, further insurance can be provided if the private pension plan is integrated with the social security programme - typically by deducting either the value of contributions to, or pension benefits from, the social security programme in calculating private pension entitiements. ${ }^{5}$ It is argued that DB plans, which calculate benefits by similar criteria, are more amenable to integration than DC plans. Thus, by varying contribution rates levied on employees in line with the variation in prospective state pensions, some reduction in pension uncertainty can be obtained. However the incidence of contribution-based integration procedures will differ from the social security outcomes across generations where private plans are "advance funded" whereas the state pension is funded on a PAYG basis.

\subsection{Inflation insurance}

SERPS benefits are fully indexed to price inflation in payment, with average earnings between the (price indexed) contributory floor and ceiling revalued in line with average earnings. For a contracted-out DB or DC scheme in the UK, inflation protection is jointly provided by the scheme provider and the government for the component which replaces SERPS, known as the Guaranteed Minimum Pension (GMP). ${ }^{6}$ It may be assumed that an accumulated DC fund, net of the GMP component, can be used to purchase an indexed annuity; thus there is the option of full indexation. However, there is no requirement that a DB plan offers full price indexation above the GMP component. Furthermore, "preserved" benefits from previous pension scheme tenures (excluding the GMP component) are

\footnotetext{
${ }^{5}$ Roughly $50 \%$ of occupational pension schemes in the UK provide some form of integration with social security.

${ }^{6}$ Under the provisions of the Pension Act 1995, the idea of a GMP component on new pension accruals has now been abandoned.
} 
indexed prior to receipt only up to a maximum average inflation rate of $5 \%$ per annum for the interval between termination of tenure and receipt of the pension benefit (for more details, see Disney, 1995).

\section{Evaluation}

The discussion of Table 1 suggests that no single form of pension exhibits dominant insurance characteristics across the range of risks examined here. There is no reason to attach equal weight to the various potential insurance properties listed there and some are indeed closely related: for example job terminations (job tenure shocks and labour market interruptions) can be regarded as forms of extreme value earning uncertainty. For highly risk averse individuals, insurance against near-to-zero stochastic shocks to earnings might be a paramount requirement, in which case pension provision by a social security programme probably dominates the other options.

Indeed, were it not for the uncertainty attached to social insurance itself, a social security programme would just about dominate all forms of private pension provision (evaluated at equal expected value) given that it provides some or almost total insurance against all the other risks identified in the Table. This is, of course, a typical result of theoretical economics as to the potential welfare-enhancing role of social security, in which it is assumed that the social security programme which is actually instituted is designed to insure against the risk which was previously uninsured. But there is an equally strong argument that social security provision in practice exhibits several salient features of the public choice literature, such as voting cyclicality and logrolling, and it is not difficult to construct models in which the level and form of social security provision is sub-optimal, particularly in the face of demographic shocks (Disney, 1996). Given such instability and uncertainty attached to social security programmes, "social insurance uncertainty" seems to be of major importance in practice, so that no form of pension provision dominates overall.

In the $\mathrm{DB}$ versus $\mathrm{DC}$ debate, the issue of earnings uncertainty versus capital market uncertainty predominates. In the simplest framework, a DB plan is characterised by incomplete insurance against earnings uncertainty, since pension entitlements are calculated on the basis of final earnings whereas a DC plan, although avoiding such risks by in effect averaging across lifetime earnings, is subject to capital market uncertainty. Such comparisons (and indeed all the comparisons described here) must be done in an equal expected value framework in order to bring out the schemes' comparative insurance properties. A number of variants of this DB v. DC comparison can be constructed: for example, in Brugiavini and Disney (1995) there is a job tenure risk (a portability cost) attached to a DB plan and rate of return uncertainty attached to a DC plan. Clearly the simulated expected utilities attached to the two plans under the equal expected value assumption depends on the form of individual preferences and the parameterisation of these risks.

As Bodie, Marcus and Merton (1988) point out, however, the DB versus DC debate is somewhat artificial: for example a DB plan could always contain an earnings averaging procedure (or indeed the insurance properties against earnings uncertainty described by Samwick, 1993) and full revaluation of preserved rights. Conversely, if a DC plan could immunise fluctuation in returns on the capital market, it would vield the average return of a DB plan invested in the same portfolio. Indeed it is possible to construct the scenario where the DB plan benefit formula contains explicit insurance against earnings uncertainty (as in the "twenty best years" formula in SERPS from 1978 to 1986) whereas pre-commitment 
of DB plan funds to a particular investment strategy in order to take advantage of the term structure of interest rates exposes the DB plan to capital market uncertainty. Thus the insurance properties of the two types of plans are reversed.

The relevant question is therefore whether a DC plan or a DB plan is more "flexible": that is whether, by suitable plan design, any combination of insurance and incentive characteristics can be combined in a plan of a DC or DB type. The standard argument is that the DC plan offers the greater flexibility: for example as to accrual structure, in the potential use of a "target benefit" criterion, in portability and in portfolio composition. Nevertheless this does not suggest that any particular DC plan offers full insurance against these various risks; indeed no plan can do this. It follows from this that the "stampede" towards DC plan coverage in the US (Gustman and Steinmeier, 1992) and to Personal Pensions in the UK arises not from any difference in their potential welfare-enhancing possibilities, but from changes in the regulatory structure, from incomplete coverage and from changing tax incentives. Companies also now perhaps perceive it as easier to unlock the "final salary" aspect of existing DB plans by initiating DC plans rather than attempting to revise the DB plan formula; a trend suggested by the survey of employer attitudes described in Disney (1995).

Overall, therefore the "pensions as insurance" debate has come to no clear conclusions. In the case of state intervention, such involvement can always be welfare-improving in theory. But there is little evidence that state provision of pensions has been motivated by realistic consideration of the insurance properties of alternative forms of provision, both by and within the state and private sectors. A revenue raising motive, ideological considerations (often leading to complete misunderstanding of the redistributive impacts of particular schemes) and the paternalist stance of government have probably been the key elements behind state intervention in the pension market.

In the case of private provision, the general consensus in the academic debate as to whether DB or DC is the ideal form of provision is that the latter is more flexible since it can replicate any "mix" of insurance possibilities offered by a DB plan. This proposition is not however generally accepted in the policy debate where it is assumed that DB plans offer the more favourable insurance properties. The different types of potential uncertainty which affect pension values outlined here suggest that this conclusion is not well founded. Given, however, the possibility of "mixed" plans: for example group provided DC plans which adopt a "target benefit" basis, and the essentially semantic nature of much of the debate, there may be the chance of a more reasoned debate in the future as to the optimal form and extent of private provision of pension insurance. 


\section{REFERENCES}

BARR, N., "Economic theory and the welfare state: A survey and interpretation", Journal of Economic Literature, 30, 1992, pp. 741-803.

BERNHEIM, B. D., "How strong are bequest motives? Evidence based on estimates of the demand for life insurance and annuities", Journal of Political Economy, 99, 5, 1991, pp. 899-927.

BODIE; Z., "Pensions as retirement income insurance", Journal of Economic Literature, 28, 1990, pp. 28-49.

BODIE, Z., MARCUS, A. and MERTON, R., "Defined benefit versus defined contribution plans: what are the real trade-offs?", 1988, pp. 139-160 in Bodie, Z., Shoven, J. B. and Wise, D. A., Pensions in the US Economy, Chicago: Chicago University Press for NBER.

BOSKIN, M. J. and SHOVEN, J. B., "Concepts and measures of earnings replacement during retirement", 1987, pp. 113-141 in Bodie, Z., SHOVEN, J. B. and WISE, D. A. Issues in Pension Economics, Chicago: Chicago University Press for NBER.

BRUGIAVINI, A., Longevity Risk and the Life-Cycle, 1990, Doctoral Dissertation, London School of Economics.

BRUGIAVINI, A., "Uncertainty resolution and the timing of annuity purchases", Journal of Public Economics, 50, 1993, pp. 31-62.

BRUGIAVINI, A. and DISNEY, R., "The choice of private pension plan under uncertainty in the UK", Institute for Fiscal Studies, Working Paper, No. 95/5, 1995, London.

CREEDY, J., State Pensions in Britain, 1982, Cambridge: Cambridge University Press for NIESR.

CREEDY, J. and DISNEY, R., Social Security in Transition: An Economic Analysis, Clarendon Press: Oxford.

CREEDY, J. and DISNEY, R., "The Australian pension scheme: some basic analytics", Economic Record, 65, 4, 1989, pp. 357-368.

CREEDY, J., DISNEY, R. and WHITEHOUSE, E., "The earnings related state pension scheme, indexation and lifetime redistribution in the UK", Review of Income and Wealth, 40, 1993, pp. 257-278.

DIAMOND, P., "A framework for social security analysis", Journal of Public Economics, 8, 1977, pp. 275-298.

DILNOT, A., DISNeY, R., JOHNSON, P. and WhITEhOUSE, E., Pensions Policy in the UK: An Economic Analysis, 1994, London: Institute for Fiscal Studies.

DISNEY, R., "Occupational pension schemes: prospects and reforms in the UK", Fiscal Studies, 16, 3, 1995, pp. 19-39.

DISNEY, R., Can We Afford to Grow Older? A Perspective on the Economics of Ageing: Cambridge, Mass: MIT Press, 1996.

DISNEY, R., GALLAGHER, T. and HENLEY, A., "Excess housing costs and the behaviour of elderly households", University of Kent, Studies in Economics, No. 94/8, 1994, Canterbury.

DISNEY, R., and WHITEHOUSE, E., "How should pensions in the UK be indexed?", Fiscal Studies, 12, 3, 1991, pp.47-61.

DISNEY, R. and WHITEHOUSE, E., The Personal Pension Stampede, London: Institute for Fiscal Studies, 1992.

DISNEY, R. and WHITEHOUSE, E., "Will younger cohorts obtain a worse deal from the UK state pension scheme?", 1993, pp. 85-103 in Casson, M. and Creedy, J. (eds) Industrial Concentration and Economic Inequality: Essays in Honour of Peter Hart, Aldershot: Edward Elgar. 
DISNEY, R. and WHITEHOUSE, E., "What are occupational pension plan entitlements worth in Britain?", Institute for Fiscal Studies, Working Paper, No. 94/1, 1994, Economica.

ECKSTEIN, Z., EICHENBAUM, M. and PELED, D., "Uncertain lifetimes and the welfare enhancing properties of annuity markets and social security", Journal of Public Economics, 26, 1985, pp. 303-326.

EICHENBAUM, M. S. and PELED, D., "Capital accumulation and annuities in an adverse selection economy", Journal of Political Economy, 95, 2, 1987, pp. 334-354.

ENGEN, E. M., GALE, W. G. and SHOLSTER, J. K., "Do saving incentives work?", Brookings Papers on Economic Activity, 1, 1994, pp. 85-179.

GUSTMAN, A. and STEINMEIER, T., "The stampede towards defined contribution plans: Fact or fiction?", Industrial Relations, 31, 1992, pp.361-369.

HEMMING, R. and KAY, J. A., "The costs of the state earnings related pension scheme", Economic Journal, 92, June 1982, pp. 300-319.

HMSO, Reform of Social Security, 1985, Cmnd 9519, Volume 3, London: HMSO.

HUBBARD, R. G., SKINNER, J. and ZELDES, S. P., "Precautionary saving and social insurance", Journal of Political Economy, 103 (2), 1995, pp. 360-399.

KUHN, P. and DAVIES, J. B., "Social security, longevity, and moral hazard", Department of Economics, McMaster University, Working Paper, No. 88/10, October 1988.

LAKONISHOK, J., SHLEIFER, A. and VISHNY, R., "The structure and performance of the money management industry", Brookings Papers on Economic Activity, Microeconomics volume, 1992, pp. 339-393.

LEATHER, P., "The potential and implication of home equity release in old age", Housing Studies, 5, 1990, pp. 3-13.

ROTHSCHILD, M. and STIGLITZ; J. E., "Equilibrium in competitive insurance markets: An essay on the economics of imperfect information", Quarterly Journal of Economics, 90, November 1976, pp. 629-649.

SAMUELSON, P. A., "Optimal social security in a life-cycle growth model", International Economic Review, 16, 3, 1975, pp. 539-544.

SAMWICK, A. A., "Wage risk compensation through employer-provided pensions", mimeo, MIT, April 1993.

SCHIOPPA, F. P., "Undesirable redistributions in the retirement public pensions scheme: the Italian case study", Centre for Economic Policy, Discussion Paper, No. 463, London, August 1990.

SINN, H. W., "Social insurance, incentives and risk taking", Plenary presentation at the 51st Congress of the International Institute of Public Finance, Lisbon, August 1995.

TURNER, J. A., Pension Policy for a Mobile Labor Force, 1993, W.E. Upjohn Institute for Employment Research, Kalamazoo, Michigan.

WILSON, C. A., "A model of insurance markets with incomplete information", Journal of Economic Theory, 16, December 1977, pp. 167-207.

WILSON, T., Pensions, Inflation and Growth, 1974, London: Heinemann. 